\title{
Class Size and Students' Anxiety in Oral Recitation
}

\author{
Jerald C. Moneva \\ .DepEd, Jagobiao National High School \\ Cebu City, Philippines \\ E-mail: monevajerald5@gmail.com
}

Leo B. Acibar

DepEd, Cebu City

Cebu City, Philippines

E-mail: leo.acibar@gmail.com

\author{
Niel O. Monding \\ Jagobiao National High School \\ Cebu City, Philippines \\ E-mail: mondingniel@gmail.com
}

Received: February 23, 2020

Accepted: March 20, 2020 Published: March 23, 2020

doi: $10.5296 /$ jsss.v7i2.16518

URL: https://doi.org/10.5296/jsss.v7i2.16518

\begin{abstract}
Anxiety is one of the greatest challenges that faced by the students nowadays. Anxiety can affect the student's productivity, performance and academic achievement in many ways. Class size plays an important role on learning of the students. Students who belong to the large or small class size can surpass this problem, it may give their co-classmate a confidence and courage in facing the anxiety they felt. This study intends to determine the association between the class size and student's anxiety in oral recitation of Jagobiao National High School. This research work uses a descriptive design with likert's scale questionnaire as being used for gathering data. After the data were being gathered, the data were then analyzed using weighted mean and chi-square in determining the relationship between the class size and
\end{abstract}


anxiety in oral recitation. 300 randomly selected students from Jagobiao National High School- Junior High School Cebu City, Philippines were asked to participate. The result of the study indicates that the class size in Jagobiao National High School has a range of forty-six to fifty students, the result revealed that the students have anxiety in oral recitation and the students' level of anxiety is slight to extremely anxious and it is also revealed that there is no association between class size and students' anxiety in oral recitation

Keywords: Anxiety, Class size, Oral recitation

\section{Introduction}

One of the methods in helping students to memorize information and boost their confidence in standing in front of the class is oral recitation. When students started to perform in front of the class they find themselves that they are the focus of the attention, as they have to address and connect themselves to their classmates and teacher. In presenting in front of the class, they feel and experience emotions like fear and anxiety that leading to excessive sweating. Ayeni and Olowe (2016) Class size defines as the exact number of students in the class that taught by the teacher in a particular time. The ratio of students and teacher is essential in the students learning and productivity in school.

Aoumeur (2017) found out that class size can affect the student's learning, productivity and the teacher's strategies in teaching. This means that class size plays an essential role for the students and teacher. Zyngier (2014) students who belongs to small class size has an essential impact to the student's achievement in school especially those students who belong to lower class community. The class size can affect learning. Although, students will always choose their preferred school that might have a large class size or small class size as long as they are learning, class size does not matter.

Raja (2017) stated that anxiety is a state of foreboding of fear caused by the expectation of things that can be threatening. Students who feel anxiety while speaking in front of the class had encountered difficulties in language and reduced their self-confidence and they made mistakes in their speech. Chandran, Munohsamy and Rahman (2015) pointed out some factors that caused people felt anxiety in speaking in front of many people and these are; afraid of making mistakes, fear of crowd, lack of preparation and confidence, and vocabulary problems. Student can overcome this anxiety in oral recitation by practicing speaking in small group or peers and then move to the larger size of audience.

In Jagobiao National High School especially in Junior High School Students, it has been observed during oral recitation that the students cannot fully express their thoughts and ideas in presenting their individual point of views of a certain topic. Students are most afraid in presenting their thoughts in class because they are afraid to commit mistake. Students who do oral recitation are having trouble in choosing a word to speak. Students are having excessive sweating and their palm is shivering like they are afraid in standing in front of the class. Afterwards they think what they did and they keep focusing on it and asking themselves if this is true or just a day dream. Most of the students in Jagobiao National High School are mostly talkative but when they asked to recite something or some part of the class discussion, 
they can't share it to the class.

Eventually, this study aims to determine the association between class size and students' anxiety in oral recitation of the students in Jagobiao National High School especially in Junior High School.

\subsection{Theoretical Background}

This study supported by Robert Cloninger Anxiety and Theories of Emotions, proposed by Robert Cloninger in 1988. The study of Robert Cloninger about anxiety and theories of emotion identify that anxiety has multidimensional phenomenon. Cloninger (1988) stated that cognitive ability to cope with the threat, subjective feelings of fear, characteristic of physiological signs of arousal and expressive or motivated behavioral action is part of anxiety's multidimensional phenomenon. In expressive or motivated behavioral action has two parts the active avoidance and passive avoidance, it also discussed that there is an impact of the person's emotion by the combination of positive and negative effect in handling anxiety.

Students who belong to large or small class size had encountered the multi-dimensional phenomenon of anxiety. When they are presenting their thoughts in front of the class, they are doing their best to present it clearly but they feel anxious on what they doing. Cloninger (1988) mentioned that one of the characteristic of physiological signs of arousal are sweating, panic and increased the heart rate. Students experience the expressive or motivated behavioral action or panic when they started to share their thoughts to the class during class hours. It might be long run for those students who are passively or actively avoidance in the class activity because they put more pressure on the activities. Students still gave their best to perform what they asked to do.

Students need to have a cognitive ability to cope with the anxiety they feel. Most of the students get this from their thoughts in the class or getting out of the situation with alibis to surpass it. The students depend on their knowledge on a particular topic even if their knowledge is not enough on dealing with that particular topic but still the important factor that the students need is to have a cognitive ability in dealing with anxiety in terms of oral recitation. Anandari (2015) states one thing that can help the students to find their strengths and weaknesses is self-reflection. Student must know how to handle their anxiety to lessen or reduce their anxiety in oral recitation. Students should find a way to help themselves in coping with anxiety to make it better in presenting something in front of the class in verbal or oral form.

Many factors caused the anxiety of the students in dealing with oral recitation and class size. The theory of Robert Cloninger can help the students to identify what they felt when they experienced anxiety in oral recitation and it gives information on how the anxiety affects the person's emotion in performing any activities on verbal or oral aspects.

\subsection{Statement of the Purpose}

The study intends to determine the relationship between the class size and anxiety in oral recitation of the students. 


\section{Mll Macrothink}

Specifically, the study seeks to answer the following sub problems;

1). What is the profile of the students who belong to a particular class size?

2). To what extent do students feel anxiety during oral recitation?

3 ). Is there an association between the profile of the students who belong to a particular class size and the student's level of anxiety in oral recitation?

Hypothesis

Null Hypothesis- there is no association between the class size and the students' anxiety in oral recitation.

Alternative Hypothesis- there is an association between the class size and the students' anxiety in oral recitation.

\subsection{Significance of the Study}

This research study will very helpful and will benefit for the following citizens;

Students will benefit this research study because they will be aware on the anxiety they feel in oral recitation and they can also minimize their anxiety by socializing their co classmates.

Parents will also benefit this study because they will be aware on how to motivate their children that have an anxiety in oral recitation.

Teacher will also benefit this study in order for them to handle and understand the student's anxiety in oral recitation. They can also make improvement to their strategies on the discussion to lessen or reduce the anxiety of the students.

The School head will also benefit this study because it will give information about the student's performance in relation to anxiety in oral recitation that cause by the class size so that the school head makes appropriate action on the class size.

The Community will also benefit this study because this will provide information that needed for the people in the community in making and building some understanding about anxiety especially in oral recitation.

Researcher will also benefit this study because they will become knowledgeable from their research study.

Future researchers will also benefit from this study for reference material for their research work.

\subsection{Definition of Terms}

To understand more about this research study, some of the terms are operationally defined. These are the following terms;

Anxiety is a state of worry and nervous that can be threatening the students.

Anxiety of oral recitation is a feeling of worry, nervous and foreboding in having an oral recitation.

Class size is the actual number of the students in the classroom.

Oral recitation is a class activity that students engage in memorizing information, recalling important things and improving thinking skills in the form of oral or verbal.

\section{Review of Related Literature}

The study was supported by the different study based on the variables of this research, Class 
Size and Student's Anxiety in Oral Recitation.

It is inevitable for students to feel anxiety especially when performing oral recitation in class. Cutrone (2009) one of greatest challenges that encountered and faced by the students when it comes to language is anxiety. Raja (2014) the main reasons why students felt anxious in public speaking was the lack of confidence. Chandran, Munohsamy and Rahman (2015) stated that one of the factors caused people felt anxiety are afraid of making mistakes, self-doubting, and vocabulary problems and Kayaoglu and Saglamel (2013) also stated that speaking difficulties, cognitive problems, teachers as a role and lack of information and preparation are considered one of the causes of language anxiety. Male (2018), revealed that most of the student has anxiety in linguistic aspects such as, speaking, writing, reading and listening. Ahmed, Pathan, Khan (2017) anxiety in English speaking language in the classroom can affect the student's achievement in school.

Several studies revealed that anxiety can affect the student's attitude in school. Derakshan and Eysenck (2009) revealed that anxiety has strong evidence that it can affect the student's productivity in school. Aghjani and amanzadeh (2017) found out that students who are anxious are those students who get lower score and has poor performance in communication. Rastegar and Karami (2015) also found out that if the anxiety in EFL learners' is high, their willingness to communicate is less and vice versa. This means that anxiety can affect attitude of students in school.

Anandari (2015) self-reflection can help students to deal with anxiety in public speaking and helps the students to identify their weakness and strength. Zhiping and Paramasivam (2013) stated that student's reaction on the teacher's strategies in discussion and technique in discussion of the teachers are connected to each other and it can affect the learning skills of the students.

In addition, Mohtasham and Farnia (2017) instructor's strategies in providing information plays an important role in speaking anxiety of the students. Iqbal, Bhatti, Parveen anqd Javaid (2017) students who belong to female group are performing better in speaking english because they can reduce their anxiety by training. Kamridah, Yassi, Arafah, and Imran (2015) suggested that to overcome the obstacles that faced by the student's level of anxiety in speaking in public, students should control the psychological aspects when speaking in public.

Moreover, Sahari, Johari and Morni (2016) recommends that teacher should be learn about the anxiety that felt by the students in order for them to feel good and being active in the class activities. Lian and Budin (2014) teachers also must understand the nature of anxiety that felt by the students to be able to design class lesson, prepare class activities and learning materials that will be capable to the students to participate in every classroom based learning activities. In addition, to reduce the magnitude of anxiety that felt by the students, teacher provides joyful teaching and creative learning activities.

There are many studies revealing that class size and student's productivity in class does not affect each other. Todd (2012) stated that class size does not affect the student's learning but it can affect the performance of the students. Ngoboka and Schultz (2002)found out that class size might not affect the academic performance of the students. 
In addition, Yusuf, Onifade and Bello (2016), also found out that class size has an impact on the student's attitude in school. Ruffina, Esther, Anastecia (2018) revealed that large class size can affect the student's academic performance and the teacher's attention. Nye, Hedges, and Konstanopoules (2000) Small class size is essential in learning. Ayeni and Olowe (2016) found out that class size can affect the student's achievement in school and it also makes learning and teaching process difficult. Aoumeur (2017) revealed that class size can affect the quality of student's learning and teacher's teaching. Parks-Stamm, Zanfonte and Palenque (2016) students' participation in class and the instructor has a strongly positive relationship with each other and could reflect a correlation of both instructor and students.

Moreover, Bahalnshal (2013) class size plays an essential role in teaching and learning. Teacher has a big role of learning of the students in instance, Omwirhiren and Anderson (2016) large class size and small class size also can affects students' academic performance. Berg (2015) found out that students who belongs to the small group are performing better than larger group of students. Students with in the school and classroom provide evidence for a positive effect of class size on their performance and productivity in school.

However, several studies give recommendations and suggestions that can prevent the effect of class sizes, Ajayi, Audu, Ajayi (2017) suggested that to minimize the effect of class size in relation to student's performance in school, government should take an action in building classrooms and facilities for the students. Zyngier (2014) suggested that schools should take an action on the effect of class size by lowering the number of students in the class. Owen and Rolfes (2015) recommends that communication is one of the best ways to encourage students who belong to small class size to find themselves that they are part of community. Hatch, Rao, and Oen (2007) suggested that by building classrooms, teacher can also have an opportunity to use different strategies and techniques in discussing their topics and providing learning for the students.

\section{Research Methodology}

This chapter discusses the methods used by the researcher, the environment, design, respondents, instrument, collection of data and data analysis.

\subsection{Design}

The research study used a descriptive correlation of the variables in determining the relationship between the class size and the students' anxiety in oral recitation.

\subsection{Environment}

The research study was conducted in Jagobiao National High School Junior High. Junior High Department has 18 classrooms that located in different building in Jagobiao National High School. It also had 4 classroom facilities that provide knowledge for technology and livelihood education TLE student such as computer, electronics, cookery, drafting, and handicraft.

\subsection{Respondent}

The study that the researcher was made was answered by the Junior High students of Jagobiao National High School- Cebu, Philippines. A total of 300 random selected respondents from Junior High was answered the survey questionnaire about the class size and students' anxiety in oral recitation. 


\subsection{Instrument}

One survey questionnaire was used for data collection in this research study and it was a Likert's scale. This survey questionnaire was adopted from the study of Nist and Diehl (1990), in gathering the data for anxiety and it was developed by the researcher to assess the students' anxiety in oral recitation. The questionnaire consists of 10 indicators that are answerable by 1-5 interpreted as (1) never; (2) rarely; (3) sometimes; (4) often; (5) always. The survey questionnaire scores were used in measuring the level of anxiety they felt and the researcher provides 5 indicators, the scores are integrated by classifications; (1-10) not anxious at all, (11-20) slightly anxious, (21-30) moderately anxious, (31-40) highly anxious, and (41-50) extremely anxious.

\subsection{Data Gathering}

The researcher asked permission from the school head, adviser or teacher involved by using a transmittal letter. The researcher gave a survey questionnaire to the respondents to answer. The researcher gave them enough time to answer the questions. Then, the researcher gave their appreciation to the respondents for the cooperation. The data gathered by the researchers was used for the data analysis, interpretation of data, findings, conclusion, and recommendation of the study.

\subsection{Statistical Treatment}

The weighted mean and chi-square was used for interpreting the collected data. The weighted mean was used for the number of respondents and their answer to the given questionnaire and getting the average of it. The chi-square was used to determine if there is a significant association between the class size and students' anxiety in oral recitation.

\section{Presentation, Analysis and Interpretation of Data}

This chapter presents the findings, analysis, discussion and interpretation of the data gathered that is reliable to the study, "Class Size and Students' Anxiety in Oral Recitation".

Table 1. Class size

\begin{tabular}{llll}
\hline $\begin{array}{l}\text { Range of } \\
\text { Class size }\end{array}$ & Frequency & PERCENT \\
\hline $41-45$ & 78 & $26.00 \%$ \\
& $46-50$ & 116 & $38.66 \%$ \\
& $51-55$ & 32 & $10.66 \%$ \\
& $56-60$ & 74 & $24.66 \%$ \\
\hline TOTAL & & 300 & $100 \%$ \\
\hline
\end{tabular}

The table above displays the number of respondents who answer the survey questionnaire in variable one, which is Class Size. Out of 300 respondents, the greatest number of the respondents who answered the survey questionnaire has $38.66 \%$ with a class of $46-50$, and followed by $26 \%$ with a class size of $41-45$, followed by $24.66 \%$ percent with a class size of 56-60 and followed by the lowest number of respondents with $10.66 \%$ that has a class size of 
51-55. The respondents who participates in answering the survey questionnaire are correctly spread according to the range of class size they belong. Majority of the students belong to the class size of 46-50 students. This result indicates that most of the students in Jagobiao National High School has a class size of 50 every room. This result was in line by the study of Ajayi and Ajayi (2017) who found out that class size can influenced student's engagement in school. Aoumeur (2017) who also found out that large class size in general can affect the teachers and students' behavior. However, Todd (2012) class size cannot affect the student's learning and progress in school. It depends on the student's attitudes towards learning on how they deal on learning process. Moreover, students who belong to this number of class size can manipulate and control their learning on what they actually doing in the class discussion and in their performance in school.

Table 2. Anxiety in Oral Recitation

\begin{tabular}{|c|c|c|}
\hline INDICATORS & $\begin{array}{l}\text { WEIGHTED } \\
\text { MEAN }\end{array}$ & INTERPRETATION \\
\hline $\begin{array}{l}\text { 1. I have visible signs of nervousness such as } \\
\text { sweating palm, shaky hands, and so on right } \\
\text { before an oral recitation. }\end{array}$ & 3.35 & Sometimes \\
\hline 2. I feel anxiousness before an oral recitation. & 3.14 & Sometimes \\
\hline 3. I feel disgusted before an oral recitation. & 2.64 & Sometimes \\
\hline $\begin{array}{l}\text { 4. I have trouble in sleeping at night before an oral } \\
\text { recitation. }\end{array}$ & 2.62 & Sometimes \\
\hline $\begin{array}{l}\text { 5. I am not comfortable in standing in front of the } \\
\text { class during oral recitation. }\end{array}$ & 3.18 & Sometimes \\
\hline $\begin{array}{l}\text { 6. I have trouble in choosing a word to use during } \\
\text { oral recitation. }\end{array}$ & 3.17 & Sometimes \\
\hline $\begin{array}{l}\text { 7. I cannot speak directly on what I want to } \\
\text { express during oral recitation. }\end{array}$ & 3.30 & Sometimes \\
\hline 8. My mind goes blank during oral recitation. & 2.76 & Sometimes \\
\hline $\begin{array}{l}\text { 9. I remember the information that I want to } \\
\text { express after oral recitation. }\end{array}$ & 3.31 & Sometimes \\
\hline 10. I day dream after oral recitation. & 2.82 & Sometimes \\
\hline OVERALL WEIGTHED MEAN & 3.03 & Sometimes \\
\hline
\end{tabular}

Legend: 1.00-1.80(Never), 1.81-2.60(Seldom), 2.61-3.40(Sometimes), 3.41-4.20(Often) \&4.21-5.00(Always).

Reference: https://muskingum.edu/ cal/database/general/anxietyquest.html

The table above presents the students' anxiety in oral recitation that has three highest weighted mean that interpreted as sometimes. The result showed that the indicator 1 "I have 
visible signs of nervousness such as sweating palm, shaky hands, and so on right before an oral recitation." has the first highest weighted mean, which followed by the indicator 9 "I remember the information that I want to express after oral recitation." has the second highest weighted mean and the indicator 7 "I cannot speak directly on what I want to express during oral recitation. "Has the third highest weighted mean and also, the 10 indicators have three lowest weighted mean, the first lowest indicator was indicator 4 ". I have trouble in sleeping at night before an oral recitation", followed by indicator 3 "I feel disgusted before an oral recitation" and lastly indicator 8 "My mind goes blank during oral recitation". While the overall weighted mean of the second variable is 3.03and it is interpreted as Sometimes. The result shows that students in Jagobiao National High School are sometimes experiencing anxiety in oral recitation. This result is in line with the findings of Mohtasham and Farnia (2017) who found out that the students' anxiety has an effect on the performance in school of the students. Lian and Budin (2014) also found out that the students are moderately anxious in terms of English language. Aghajana and Amanzadeh (2017) students who are anxious and communication performance was considered to correlate to each other. Moreover, students who felt anxious when standing in front of many people has an impact of their confidence, performance in school and some other factor that causes student's anxiety.

Table 3. Level of Anxiety in Oral Recitation

\begin{tabular}{|c|c|c|c|}
\hline $\begin{array}{ll}\text { NUMBER } & \text { OF } \\
\text { INDICATORS } & \end{array}$ & FREQUENCY & PERCENT & INTERPRETATION \\
\hline $1-10$ & 0 & $0 \%$ & Not anxious at all \\
\hline $11-20$ & 12 & $4.00 \%$ & Slightly anxious \\
\hline $21-30$ & 154 & $51.33 \%$ & Moderately anxious \\
\hline $31-40$ & 121 & $40.33 \%$ & Highly anxious \\
\hline $41-50$ & 13 & $4.33 \%$ & Extremely anxious \\
\hline TOTAL & 300 & $100 \%$ & \\
\hline
\end{tabular}

The table above displays the level of anxiety of the students in Jagobiao National High School when it comes to oral recitation. The greatest number of respondents who have a score of 21-30 with a percent of $51.33 \%$ which interpreted as moderately anxious and followed by the second greatest number of respondents with a score of 31-40 with a percent of $40.33 \%$ and interpreted as high anxious and lastly, the lowest number of respondents who have a score of $11-20$ with a percent of $4.00 \%$ interpreted as slightly anxious. More than $50 \%$ of the respondents are feel anxious. The result shows that majority of the students that answered the questionnaire was slight to extremely anxious in oral recitation. Therefore, most of the students in Jagobiao National High School are anxious in oral recitation. This result was Reiterates and aligned with the findings of Lian and Budin (2014) who found out that students are moderately anxious in terms of English language. The study of Ahmed, Pathan and Khan (2017) anxiety can affect the students performance in foreign English language 
classroom. This means that one of the causes why students feel anxiety is the magnitude of classroom and presence of their co-classmates. Iqbal, Bhatti, Parveen and Javaid (2017) suggests that to reduce the anxiety that feel by the students, students must enhanced and developed their speaking ability. Moreover, students who felt anxiety must overcome the fear in oral recitation to feel better by making some adjustments and getting used to communicate by their co classmates and, also to people around them.

Table 4. Class Size and Anxiety in Oral Recitation

\begin{tabular}{llll}
\hline & Value & Df & Asymp. Sig. (2-sided) \\
\hline Pearson Chi-Square & $2.385 \mathrm{E} 2^{\mathrm{a}}$ & 232 & .370 \\
Likelihood Ratio & 229.418 & 232 & .536 \\
Linear-by-Linear Association & .438 & 1 & .508 \\
N of Valid Cases & 300 & & \\
\hline
\end{tabular}

In this table, the result shows that there is no significant association between the class size and student's anxiety in oral recitation because the p-value is $(0.370)$ greater than the significance level of $\alpha 0.05$. ( $p=0.370>0.05)$. It is concluded that class size and students' anxiety in oral recitation is not associated with each other. Students feel anxiety when they are reciting something in front of the class and affect their learning because cannot express their thought clearly but not because of the presence of many students. This result is in line by the findings of Todd (2012) class sizes cannot affect the students' learning. In addition, Ngoboka and Schultz (2002) class sizes might not affect the academic performance of the students. Even though class size doesn't affect the students' learning, students who belong to the large or small class size should perform better in class. However, Omwirhiren and Anderson (2016) students teacher must take an action to those students who belong to small or large class size to improve the students' productivity and performance in school.

\section{Summary of Findings, Conclusion and Recommendation}

This chapter includes the summary of findings, conclusion, and recommendations that is applicable to the study “Class Size and Students' Anxiety in Oral Recitation”.

\subsection{Summary of findings}

The result of this research study shows that class sizes in Jagobiao National High School has a ranges of forty-one to fifty students.

Based on the result of this research study, most of the students in Jagobiao National High School are anxious when it comes to oral recitation and most of the student's level of anxiety is moderate.

However, the study revealed that there is no significant association between the class size and the student's level of anxiety in oral recitation.

\subsection{Conclusion}

Class size is essential in learning and most of the students who belong to a particular class 
size tends to be productive in school. The anxiety of the students is inevitable during oral recitation. Class size and the students' level of anxiety in oral recitation of junior high school are not associated with each other. The students' level of anxiety in oral recitation does not have an effect when class size is not constant. Although anxiety gives more pressure in the students who are presenting their thoughts in front of the class verbally or orally, the nature of the anxiety itself is one of the cause why students felt anxiety in oral recitation and it is not because of the presence of many students. Students need to have self-confidence in order to face the anxiety they felt.

\subsection{Recommendation}

Base on the findings and conclusions, the researcher made the following recommendations:

1). Students must continue their strategy in coping their anxiety in oral recitation such as practicing speaking in front of many people and getting comfortable of each and every one.

2). Teachers must adjust their techniques in discussing their topic so that students can catch up all the topics that the teacher discussing.

3). Both teacher and students raise an awareness of anxiety in oral recitation and motivate them to recognize anxiousness and assist them to reduce their anxiety.

4). School head can also request a fund to the school division to build new classrooms facilities to prevent the effect of class size and to perform the students better in class.

\section{Limitation of the Study}

Although the research paper was carefully prepared, the research is aware of the limitations. The respondent of this research study is small, the research focused only on the junior high school students. The data that was being call do not represent the majority of the students. In addition, the researcher used an adoptive research instrument from other research paper but it was not validated.

\section{References}

Aghajani, M., \& Amanzadeh, H. (2017). The effect of anxiety on speaking ability: an experimental study on EFL learners. Journal of Applied Linguistics and Language Research, 4(7), 154-164.

Ahmed, N., Pathan, Z. H., \& Khan, F. S. (2017). Exploring the causes of English language anxiety among postgraduate students of university of balochistan, Pakistan. International Journal of English Linguistics, 7(2), 99-105. https://doi.org/10.5539/ijel.v7n2p99

Ajayi, O., Audu, C., \& Ajayi, E. (2017). Influence of class size on student's classroom discipline, engagement and communication: a case study of senior secondary school in Ekiti state, Nigeria. Sky Journal of Educational Research, 5(5), 60-67. https://doi.org/10.31235/ osf.io/sxpwk

Anamdari, C. L. (2015). Indonesian EFL students' anxiety in speech production: possible causes and remedy. TEFLIN Journal, 26(1), 1-16. https://doi.org/10.15639/teflinjournal. v26i1/1-16

Aoumeur, H. (2017). The impact of class size on teaching and learning English as a foreign language: the case of the department of English at Abdel Hamid ibn badis university. Arab World Research Journal, 8(2), 349-361. https://doi.org/10.2139/ssrn.3005591 
Ayeni, O. G., \& Olowe, M. O. (2016). The Implication of Large Class Size in the Teaching and Learning of Business Education in Tertiary Institution in Ekiti State. Journal of Education and Practice, 7(34), 65-69.

Bahanshal, D. (2013). The effect of large classes on English teaching and learning in Saudi secondary schools. English language Teaching, 6(11), 49-59. https://doi.org/10.5539/ elt.v6n11p49

Berg, D. (2015). The relationship between class size and active twitter participation in the engineering classroom. American Society for Engineering Education. https://doi.org/10. 18260/p.24904

Cloninger, R. (1988). Anxiety and theories of emotion. Classifications, Etiological Factors and Associated Disturbances, 2, 1-30.

Cutrone, P. (2009). Overcoming Japanese EFL learners' fear of speaking. Language Studies Working Papers, 1, 55-63.

Derakshan, N., \& Eysenck, M. (2009). Anxiety, processing efficiency, and cognitive performance. European Psychologist, 14(2), 168-176. https://doi.org/10.1027/1016-9040.14. 2.168

Graue, E., Hatch, K., Rao, K., \& Oen, D. (2007). The wisdom of Class-size reduction. American Educational Research Journal, 44(3), 670-700. https://doi.org/10.3102/0002831 207306755

Iqbal, A., Bhatti, M. S., Parveen, S., \& Javaid, Z. (2017). Effect of speech anxiety on students' performance at secondary level. Journal of Managerial Sciences, 11(3), 108-116.

Kamridah, Yassi, A. H., Arafah, B., \& Imran, N. (2015). Correlation between level of anxiety and public speaking performance through systematic learning approach in foreign language. International Journal of Science and Research, 5(9).

Kayaoglu, M. N., \& Saglamel, H. (2013). Students' perceptions of language anxiety in speaking classes. Journal of History Culture and Art Research, 2(2), 142-160. https://doi.org/10.7596/taksad.v2i2.245

Lian, L., \& Budin, M. (2014). Investigating the relationship between English language anxiety and the achievement of school based oral English test among Malaysian form four students. International Journal of Learning, Teaching and Educational Research, 2(1), 67-79.

Male, H. (2018). Senior high school students' anxiety towards language learning skills. Journal of English Teaching, 4(1), 1-16. https://doi.org/10.33541/jet.v4i1.784

Mohtasham, L., \& Farnia, M. (2017). English speaking anxiety: a study of the effect of gender on Iranian EFL university students' perceptions. International Journal of Research in English Education, 2(4), 66-79. https://doi.org/10.29252/ijree.2.4.66

Munohsamy, T., Rahman, M., \& Chandran, S. K. (2015). Anxiety in oral presentations among itb students.

Ngoboka, P., \& Schultz, B. (2002). The effect of class size on student academic performance in a principle of microeconomics course. Proceedings of the Midwest Business Economics Association.

Nist, P., \& Diehl, M. (1990). PHCC test anxiety questionnaire. 
Nye, B., Hedges, L., \&Konstantopoulos, S. (2000). The effect of small classes on academic achievement: the results of the Tennessee class size experiment. American Educational Research Journal, 37(1), 123-151. https://doi.org/10.3102/00028312037001123

Omwirhiren, E., \& Anderson, F. (2016). Effect of class size and students' attitude on academic performance in chemistry at demonstration secondary school, Ahmadi bello university Zaria, Nigeria. Journal of Research \& Methods in Education, 10(6), 1-6.

Owen, C., \& Rolfes, D. (2015). Communication class size and professional identity. American Society for Engineering Education. 1-12. https://doi.org/10.18260/p.23705

Parks-Stamm, E., Zafonte, M., \& Palenque, S. (2016). The effects of instructor participation and class size on students participation in an online class discussion forum. British Journal of Educational Technology, 1-10. https://doi.org/10.1111/bjet.12512

Raja, F. (2017). Anxiety level in students of public speaking: causes and remedies journa of educational development. Journal of Education and Educational Development, 4(1), 94-105. https://doi.org/10.22555/joeed.v4i1.1001

Rastegar, M., \& Karami, M. (2015). On the relationship between foreign language classroom anxiety, willingness to communicate and scholastic success among Iranian EFL learners. Theory and Practice in Language Studies, 5(11), 2387-2394. https://doi.org/10.17507/tpls. 0511.25

Ruffina, A., Esther, A., \& Anastecia, I. (2018). Impact of class size on students' academic performance in biology in idemili north local government area of Anambra state. International Journal of Education and Evaluation, 8(4), 22-32.

Sahari, S. H., Johari, A., \& Morni, A. (2016). Language anxiety among adult learners in uitmsarawak. European Journal of Language and Literature Studies, 2(3) 105-110. https://doi.org/10.26417/ejls.v6i1.p105-110

Todd, R. (2012). The effects of class size on English learning at a Thai university. International Association of Research in Foreign Language Education and Applied Linguistics. ELT Research Journal, 1(1), 80-88.

Yusuf, T. A., Onifade, C. A., \& Bello, O. S. (2016). Impact of class size on learning, behavioral and gopeneral attitudes of students in secondary schools in Abeokuta, Ogun State Nigeria. Journal of Research Initiatives, 2(1), 1-16.

Zhiping, D., \& Paramasivam, S. (2013). Anxiety of speaking English in class among international students in a Malaysian university. International Journal of Education and Research, 1(11), 1-16.

Zyngier, D. (2014). Class size and academic results, with a focus on children from culturally, linguistically and economically disenfranchised communities. Evidence Base, 1, 1-23. https://doi.org/10.21307/eb-2014-001 


\section{Appendix}

Appendix 1: class size and students' level of anxiety

(likert's scale)

Name:

Date:

Grade \& Section:

Class Size:

Directions: Rate yourself honestly from 1-5 that based on what you actually do before, during and after oral recitation.

Legend:

5- Always 4- Often 3-Sometimes 2-Rarely 1-Never

\begin{tabular}{|c|c|c|c|c|c|}
\hline Anxiety in Oral Recitation & 5 & 4 & 3 & 2 & 1 \\
\hline $\begin{array}{l}\text { 1. I have visible signs of nervousness such as sweating palm, shaky hands, } \\
\text { and so on right before an oral recitation. }\end{array}$ & & & & & \\
\hline 2. I feel anxiousness before an oral recitation. & & & & & \\
\hline 3. I feel disgusted before an oral recitation. & & & & & \\
\hline 4. I have trouble in sleeping at night before an oral recitation. & & & & & \\
\hline $\begin{array}{l}\text { 5. I am not comfortable in standing in front of the class during oral } \\
\text { recitation. }\end{array}$ & & & & & \\
\hline 6. I have trouble in choosing a word to use during oral recitation. & & & & & \\
\hline 7. I cannot speak directly on what I want to express during oral recitation. & & & & & \\
\hline 8. My mind goes blank during oral recitation. & & & & & \\
\hline 9. I remember the information that I want to express after oral recitation. & & & & & \\
\hline 10. I day dream after oral recitation. & & & & & \\
\hline
\end{tabular}

Reference:https://www.google.com/amp/s/dokumen.tips/amp/documents/test-anxiety-questio nnaire-central-nist-and-diehl-1990-developed-a-short.html

\section{Copyright Disclaimer}

Copyright for this article is retained by the author(s), with first publication rights granted to the journal.

This is an open-access article distributed under the terms and conditions of the Creative Commons Attribution license (http://creativecommons.org/licenses/by/3.0/). 